\title{
Growth hormone 1 gene (GH1) polymorphisms as possible markers of the production potential of beef cattle using the Brazilian Canchim breed as a model
}

\author{
Luiz Guilherme G. Silveira ${ }^{1}$, Luiz R. Furlan ${ }^{1}$, Rogério A. Curi ${ }^{1}$, André Luiz J. Ferraz ${ }^{1}$, \\ Maurício M. de Alencar ${ }^{2}$, Luciana C.A. Regitano ${ }^{2}$, Cyntia L. Martins ${ }^{1}$, Mário de Beni Arrigoni ${ }^{1}$, \\ Liliane Suguisawa $^{1}$, Antônio C. Silveira ${ }^{1}$ and Henrique N. de Oliveira ${ }^{1}$ \\ ${ }^{I}$ Departamento de Melhoramento e Nutrição Animal, Faculdade de Medicina Veterinária e Zootecnia, \\ Universidade Estudual Paulista “Júlio de Mesquita Filho”, Botucatu, SP, Brazil. \\ ${ }^{2}$ Empresa Brasileira de Pesquisa Agropecuária, Centro de Pesquisa de Pecuária do Sudeste, \\ Fazenda Canchim, São Carlos, SP, Brazil.
}

\begin{abstract}
The growth hormone 1 gene (GH1) is a candidate gene for body weight and weight gain in cattle since it plays a fundamental role in growth regulation. We investigated the GH1 gene Alul and Ddel restriction enzyme polymorphisms, located 149 bp apart in the cattle genome, as possible markers of the production potential of Canchim crossbreed cattle, a 5/8 Charolais (Bos taurus) and 3/8 Nelore (Bos indicus) breed developed in Brazil, by evaluating the birth weight, weaning weight, yearling weight and plasma insulin-like growth factor-1 (IGF-1) concentration of 7 month to 10 months old Canchim calves $(n=204)$ of known genealogy and which had been genotyped for the Alul and Ddel markers. Our results showed significant effect $(p<0.05)$ between the homozygous $D d e l+/ D d e l+$ polymorphism and the estimated breeding value for weaning weight (ESB-WW), while the Alul leucine homozygous (L/L) and leucine/valine (L/V) heterozygous polymorphisms showed no significant effect on the traits studied. The restriction sites of the two enzymes led to the formation of haplotypes which also exerted a significant effect $(p<0.05)$ on the ESB-WW, with the largest difference being $8.5 \mathrm{~kg}$ in favor of the homozygous L plus Ddel+/L plus Ddel+ genotype over the heterozygous L plus Ddel-/V plus Ddel+ genotype.
\end{abstract}

Key words: beef cattle, polymorphism, growth hormone, candidate gene.

Received: September 14, 2007; Accepted: March 13, 2008.

\section{Introduction}

The growth hormone $1(G H 1)$ gene is a candidate gene for body weight and weight gain in cattle since it plays a fundamental role in growth regulation. The $\mathrm{GH}$ protein is a single-chain polypeptide consisting of 191 amino acids and is synthesized and secreted by the anterior pituitary gland under the hypothalamic control of two hormones, GH-releasing hormone (GHRH), which increases the secretion of $\mathrm{GH}$, and somatotropin release-inhibiting factor (SRIF, also called somatostatin) which inhibits its secretion (Nicoll et al., 1986). It is known that GH is the main regulator of postnatal somatic growth, stimulating anabolic processes such as cell division, skeletal growth and protein

Send correspondence to Henrique N. de Oliveira. Departamento de Melhoramento e Nutrição Animal, Faculdade de Medicina Veterinária e Zootecnia, Universidade Estudual Paulista "Júlio de Mesquita Filho", 18618-000 Botucatu, SP, Brazil. E-mail: hnunes@fca. unesp.br. synthesis and is involved in nutrient partition by way of regulating the oxidation rate of fats (lipolytic activity), inhibition of glucose transport to peripheral tissues and the regulation of ribosomal activity involved in translation, which, in turn, influences protein synthesis (Goodman, 1993).

The effects of some GH1 gene polymorphisms have been widely studied in beef cattle (Switonski, 2002) and the proximity between some of these polymorphisms, which can be characterized using different restriction enzymes, suggests a strong linkage between them. The presence of the $A l u$ I restriction site corresponds to the presence of the amino acid leucine (L) at position 127 in the polypeptide chain of cattle GH, whereas the absence of this site indicates the presence of valine $(\mathrm{V})$ at the same position. The presence of the DdeI restriction site corresponds to the presence of an adenine nucleotide in the cattle $G H 1$ gene sequence $(D d e l+)$, while the absence of this site (DdeI-) indicates the presence of a cytosine nucleotide at the same po- 
sition. These two polymorphisms can be used as markers but, however, no studies are available in the literature regarding the combined segregation of these markers or the effects of the haplotypes formed on cattle production traits.

The objective of the study described in this paper was to characterize GH1 gene polymorphisms as possible markers of the production potential of Canchim cattle by evaluating the individual and combined effects associated with these markers on body weight traits and the plasma concentration of the polypeptide hormone insulin-like growth factor-1 (IGF-1), which has important effects on growth.

\section{Material and Methods}

We used 108 male and 96 female $(n=204)$ Canchim calves, ranging in age from 7 months to 10 months, of known genealogy and belonging to the Brazilian Agricultural Research Corporation - Embrapa (Empresa Brasileira de Agropecuária - Embrapa) herd at Canchim Farm, Municipality of São Carlos, São Paulo, Brazil. The calves were weaned during the May, June and July (autumn/winter in the southern hemisphere) of 1999 and they represent the progeny of 10 bulls with the half-sib group varying between 8 and 34 animals. Canchim crossbreed cattle, developed in Brazil, are 5/8 Charolais (Bos taurus) and 3/8 Nelore (Bos indicus).

Blood samples were collected from the calves for the separation of the leukocyte layer, used for extraction of DNA, and the blood plasma layer, used for the quantification of IGF-1. Genomic DNA was extracted from leukocytes according to the method of Zadworny and Kuhnlein, modified by Miretti MM (1998, MSc Dissertation, University of São Paulo, Ribeirão Preto, SP, Brazil). Plasma IGF-1 concentrations were determined by radioimmunoassay using the Active IGF1 DSL-5600 kit (Diagnostic Systems Laboratories, Inc., USA) according to the instructions of the manufacturer.

The $G H 1$ gene was genotyped using the polymerase chain reaction and restriction fragment length polymorphism (PCR - RFLP) analysis using the forward (5'-TAG GGG AGG GTG GAA AAT GGA-3') and reverse (5'-GAC ACC TAC TCA GAC AAT GCG-3') primer pair published by Gordon et al. (1983) to amplify a 404-bp fragment located between positions +1405 and +1808 , comprising the end of the fourth intron, the fifth exon and the initial portion of the 3' UTR region. The Alu I and Dde I restriction enzyme map for the fragment being shown in Figure 1. The amplification reactions were carried out in a final volume of $25 \mu \mathrm{L}$ containing $100 \mathrm{ng}$ of DNA, $0.5 \mu \mathrm{M}$ of each primer, $2.5 \mu \mathrm{L}$ of $10 \mathrm{x}$ PCR buffer $(10 \mathrm{mM}$ Tris- $\mathrm{HCl}$, $\mathrm{pH}$ 9.0, $1.5 \mathrm{mM} \mathrm{MgCl}_{2}$ and $\left.50 \mathrm{mM} \mathrm{KCl}\right), 100 \mu \mathrm{M}$ of dNTPs and 0.5 units of Taq DNA polymerase (Invitrogen, USA). After initial denaturation at $94{ }^{\circ} \mathrm{C}$ for $120 \mathrm{~s}$, amplification was carried out using 40 cycles at $94^{\circ} \mathrm{C}$ for $30 \mathrm{~s}, 59^{\circ} \mathrm{C}$ for

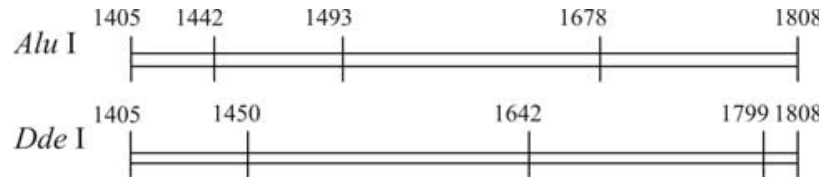

Figure 1 - Restriction map for the $A l u \mathrm{I}$ and $D d e \mathrm{I}$ enzymes between positions 1405 and 1808 of the cattle growth hormone 1 (GH1) gene (GenBank Gi: 163091). Three restriction sites are shown for each enzyme (positions 1442, 1493 and 1678 for AluI and 1450, 1642 and 1799 for DdeI), with the $A l u$ I polymorphism being identified when nucleotide change occurs at position 1493 and the DdeI polymorphism when it occurs at position 1642 .

$80 \mathrm{~s}$ and $72{ }^{\circ} \mathrm{C}$ for $90 \mathrm{~s}$, followed by a final extension step at $72{ }^{\circ} \mathrm{C}$ for $5 \mathrm{~min}$. Aliquots of the amplification products $(15 \mu \mathrm{L})$ were digested, separately, with 5 units of $A l u \mathrm{I}$ (Invitrogen, USA) and 5 units of DdeI (Invitrogen, USA) at $37{ }^{\circ} \mathrm{C}$ for $2.5 \mathrm{~h}$ and DNA fragments separated on $1.8 \%$ $(\mathrm{w} / \mathrm{v})$ agarose gel in a horizontal electrophoresis system using a 100-bp molecular weight standard (Invitrogen, USA) to calculate the size of the fragments, which were visualized by ethidium bromide staining and exposure to ultraviolet light. The possible genotypes, characterized in function of the restriction fragments, for both $G H 1$ gene polymorphism are presented in Table 1.

Analysis of the data consisted of the calculation of the allele and genotype frequencies for the loci determined with each restriction enzyme. Due to the proximity of the two restriction sites (149 bp), the independent segregation of the two loci was tested. After the confirmation of the formation of the haplotypes we applied a chi-square test of the SAS program (SAS, 1999) to the data to verify if the haplotype segregation conformed to the Hardy-Weinberg law.

The isolated effects of the genotypes and the combined effects of the two loci on estimated breeding values for birth weight, weaning weight, yearling weight and plasma IGF-1 concentration were evaluated using the GLM procedure of the SAS program (SAS, 1999). These breeding values were estimated based on data obtained from the Canchim Farm, with the genetic parameters being estimated on the same basis. For the analysis of IGF-1 concen-

Table 1 - Polymerase chain reaction restriction fragment length polymorphism (PCR-RFLP) informative fragments of genotyping of the growth hormone 1 gene $(G H 1)$ polymorphisms of Canchim calves.

\begin{tabular}{ll}
\hline Polymorphism and genotype & Informative fragments (bp) \\
\hline AluI & \\
$\mathrm{L} / \mathrm{L}$ & $185,131,51$ and 37 \\
$\mathrm{~L} / \mathrm{V}$ & $236,185,131,51$ and 37 \\
$\mathrm{~L} / \mathrm{L}$ & 236,131 and 37 \\
\hline Dde $\mathrm{I}$ & \\
$D d e \mathrm{I}+/ D d e \mathrm{I}+$ & $192,157,45$ and 9 \\
$D d e \mathrm{I}+/ D d e \mathrm{I}-$ & $349,192,157,45$ and 9 \\
DdeI-/DdeI- & 349,45 and 9 \\
\hline
\end{tabular}


tration, genetic parameters estimated for the taurine Angus breed were used (Davis et al., 2003).

Using the same genetic parameters, a mixed model analysis was performed to determine the average effects of the $A l u \mathrm{I} D d e \mathrm{I}$ haplotypes. For these analyses we considered the presence of three haplotypes in the population, identified as L plus DdeI+, L plus DdeI- and V plus DdeI+, and regression of the number of $\mathrm{L}$ plus $D d e \mathrm{I}+$ and L plus DdeIhaplotypes in the genotype of each calve was added to the statistical model. Regression of the third haplotype was not included since the number of $\mathrm{V}$ plus $D d e \mathrm{I}+$ haplotype in the genotype is completely determined by the sum of the number of the other two haplotypes. The average effects of haplotype substitution were obtained as regression coefficients. The MTDFREML program (Boldman et al., 1995) was used for these analyses and the model included the combined effect of sex and month of birth, haplotype effects and random effect of the animal.

\section{Results and Discussion}

The $\mathrm{L}$ and $\mathrm{V}$ genetic variants of the $A l u \mathrm{I}$ site polymorphism were observed in the Canchim calves studied but the V/V genotype was not detected, while for the DdeI site polymorphism both $D d e \mathrm{I}+$ and $D d e \mathrm{I}$ - alleles were observed and the three possible genotypes (Dde $\mathrm{I}+/ D d e \mathrm{I}+$, $D d e \mathrm{I}+/ D d e \mathrm{I}-$, DdeI-/DdeI-) were detected. The genotype and allele frequencies (f) at the loci determined with the two restriction enzymes are shown in Table 2. For the $A l u \mathrm{I}$ polymorphism the most frequent genotype was $\mathrm{L} / \mathrm{L}$ ( $\mathrm{f}=0.82$ ), whereas the heterozygous $\mathrm{L} / \mathrm{V}$ genotype was present at only a low frequency $(\mathrm{f}=0.18)$. The distribution of $D d e$ I genotypes in the calves showed the heterozygous $D d e \mathrm{I}+/ D d e \mathrm{I}$ - genotype being the most frequent $(\mathrm{f}=0.50)$, followed by the homozygous DdeI-/DdeI- $(\mathrm{f}=0.26)$ and $D d e \mathrm{I}+/ D d e \mathrm{I}+(\mathrm{f}=0.24)$ genotypes.

Table 2 - Genotype and allele frequencies of the AluI and DdeI polymorphisms in exon 5 of the growth hormone 1 gene (GHI) of Canchim calves.

\begin{tabular}{ll}
\hline Polymorphism, genotype and allele & Frequency \\
\hline AluI polymorphism $(\mathrm{n}=203$ animals $)$ & \\
L/L genotype & 0.818 \\
L/V genotype & 0.182 \\
V/V genotype & 0.000 \\
L allele & 0.909 \\
V allele & 0.091 \\
\hline$D d e I$ polymorphism $(\mathrm{n}=200$ animals $)$ & \\
$D d e \mathrm{I}+/ D d e \mathrm{I}+$ genotype & 0.240 \\
$D d e \mathrm{I}+/ D d e \mathrm{I}-$ genotype & 0.495 \\
$D d e \mathrm{I}-/ D d e \mathrm{I}-$ genotype & 0.265 \\
$D d e \mathrm{I}+$ allele & 0.488 \\
$D d e \mathrm{I}-$ allele & 0.512 \\
\hline
\end{tabular}

Simple observation of the combined distribution of the genotypes determined by the two polymorphisms showed that they were not independent. This finding was expected because of the proximity of the restriction sites of the two enzymes and, since the population was derived from crossings, there was a strong linkage disequilibrium which was confirmed by the chi-square test. Based on the combined distribution, only three haplotypes were observed in the population. The absence of calves with the $\mathrm{L}$ plus $D d e \mathrm{I}-/ \mathrm{V}$ plus $D d e \mathrm{I}$ - genotype suggests that no gametes without the restriction sites for the two enzymes were formed. Thus the haplotypes L plus Dde $\mathrm{I}+(\mathrm{f}=0.40)$, L plus $D d e \mathrm{I}-(\mathrm{f}=0.51)$ and $\mathrm{V}$ plus $D d e \mathrm{I}+(\mathrm{f}=0.09)$ were detected but not $\mathrm{V}$ plus DdeI-. The observed and expected genotypes of haplotypes showed that the population studied was in equilibrium for this compound locus (Table 3 ).

The AluI genotypes showed no significant differences $(p>0.05)$ regarding any of the estimated breeding values or the plasma IGF-1 levels, although the homozygous L/L genotype did show higher weaning and yearling weights and IGF-1 values than the L/V genotype (Table 4). With respect to the DdeI polymorphism shown in Table 4, significant differences between genotypes $(p<0.05)$ only occurred for weaning weight, with the $D d e \mathrm{I}+/ D d e \mathrm{I}+$ genotype showing an approximately $5 \mathrm{~kg}$ higher weaning weight than the heterozygous $D d e \mathrm{I}+/ D d e \mathrm{I}-$ genotype. It is also interesting to note that the weaning and yearling weights for the $D d e$ I-/DdeI- homozygotes were intermediate between the $D d e \mathrm{I}+/ D d e \mathrm{I}+$ and $D d e \mathrm{I}+/ D d e \mathrm{I}-$ values. For the combined $A l u \mathrm{I}$ and $D d e \mathrm{I}$ genotypes only weaning weight showed significant differences $(\mathrm{p}<0.05)$ between genotypes, with the difference between the highest and lowest value being greater than $8.5 \mathrm{~kg}$ (Table 5). Regarding the average effects of haplotype substitution, the substitution of L plus DdeIfor L plus DdeI+ produced a significant difference $(p<0.05)$ for weaning weight only $(+3.56 \mathrm{~kg})$, which also presented a significant difference between genotypes (Table 6).

Table 3 - Observed and expected frequencies of each genotype in Canchim cattle considering the combined distribution of the AluI and DdeI polymorphisms in the amplified fragments of the growth hormone 1 gene (GH1) gene of Canchim calves

\begin{tabular}{lll}
\hline & \multicolumn{2}{c}{ Frequency $^{1}$} \\
\cline { 2 - 3 } Genotype & \multicolumn{1}{c}{ Observed } & Expected \\
\hline L plus DdeI+/L plus DdeI+ & $0.175(35)$ & $0.158(31.6)$ \\
L plus DdeI+/L plus DdeI- & $0.380(76)$ & $0.405(81.1)$ \\
L plus DdeI+/V plus DdeI+ & $0.065(13)$ & $0.074(14.7)$ \\
L plus DdeI-/L plus DdeI- & $0.260(52)$ & $0.260(52)$ \\
L plus DdeI-/V plus DdeI+ & $0.120(24)$ & $0.094(18.9)$ \\
V plus DdeI+/V plus DdeI+ & $0.000(0)$ & $0.009(1.7)$ \\
\hline
\end{tabular}

${ }^{1}$ The number of observed and expected frequencies in the animals is shown in parentheses. 
Table 4 - Mean estimated breeding values (EBV) for birth weight (BW), weaning weight (WW), yearling weight (YW) and mean plasma insulin-like growth factor-1 (IGF-1) concentration for different genotypes of the growth hormone 1 gene $(G H 1)$ polymorphisms $A l u I$ and $D d e I$ of Canchim calves.

\begin{tabular}{|c|c|c|c|c|}
\hline Polymorphism and genotype & EBV-BW & EBV-WW (*) & EBV-YW & IGF-1 \\
\hline \multicolumn{5}{|l|}{ AluI } \\
\hline $\mathrm{L} / \mathrm{L}$ & $-0.0114 \pm 2.04$ & $4.6527 \pm 8.80$ & $7.3141 \pm 9.08$ & $141.07 \pm 79.72$ \\
\hline $\mathrm{L} / \mathrm{V}$ & $0.1998 \pm 1.65$ & $1.8626 \pm 7.80$ & $4.1700 \pm 8.07$ & $128.50 \pm 87.70$ \\
\hline \multicolumn{5}{|l|}{ DdeI } \\
\hline$D d e \mathrm{I}+/ D d e \mathrm{I}+$ & $0.4718 \pm 2.29$ & $7.8330 \pm 9.86$ & $8.6167 \pm 7.72$ & $140.24 \pm 82.00$ \\
\hline$D d e \mathrm{I}+/ D d e \mathrm{I}-$ & $0.0199 \pm 1.78$ & $2.8291 \pm 7.96$ & $5.5099 \pm 9.41$ & $136.42 \pm 80.20$ \\
\hline DdeI-/DdeI- & $-0.3694 \pm 1.97$ & $3.3481 \pm 8.05$ & $7.4510 \pm 8.95$ & $141.84 \pm 83.69$ \\
\hline
\end{tabular}

* Significant difference between genotype means obtained for the Dde I polymorphism (F test, $\mathrm{p}<0.05$ ).

Table 5 - Mean estimated breeding values (EBV) for birth weight (BW), weaning weight (WW), yearling weight (YW) and mean plasma insulin-like growth factor-1 (IGF-1) concentration for the combined growth hormone 1 gene (GHI) polymorphisms AluI and DdeI genotypes of Canchim calves.

\begin{tabular}{lcccc}
\hline Genotype & EBV-BW & EBV-WW $(*)$ & EBV-YW & IGF-1 \\
\hline L plus $D d e \mathrm{I}^{+} / \mathrm{L}$ plus $D d e \mathrm{I}^{+}$ & $0.5336 \pm 2.43$ & $8.6995 \pm 10.13$ & $8.8681 \pm 8.06$ & $144.62 \pm 84.46$ \\
L plus $D d e \mathrm{I}+/ \mathrm{L}$ plus $D d e \mathrm{I}^{-}$ & $-0.0198 \pm 1.84$ & $3.6879 \pm 8.18$ & $6.5183 \pm 9.61$ & $138.92 \pm 75.61$ \\
L plus $D d e \mathrm{I}^{+} / \mathrm{V}$ plus $D d e \mathrm{I}^{+}$ & $0.2966 \pm 1.84$ & $5.3780 \pm 8.89$ & $7.9042 \pm 6.97$ & $128.45 \pm 76.90$ \\
L plus $D d e \mathrm{I}-/ \mathrm{L}$ plus $D d e \mathrm{I}-$ & $-0.3694 \pm 1.96$ & $3.3481 \pm 8.05$ & $7.4510 \pm 8.91$ & $141.84 \pm 83.69$ \\
L plus $D d e \mathrm{I}-$ /V plus $D d e \mathrm{I}^{+}$ & $0.1492 \pm 1.59$ & $0.0285 \pm 6.58$ & $2.2218 \pm 8.04$ & $128.52 \pm 94.62$ \\
\hline
\end{tabular}

* Significant difference between means ( $\mathrm{F}$ test, $\mathrm{p}<0.05$ ).

Table 6 - Average effects of haplotype substitution according to the combined distribution of the growth hormone 1 gene (GH1) AluI and DdeI polymorphisms on birth weight (BW), weaning weight (WW), yearling weight (YW) and mean plasma insulin-like growth factor-1 (IGF-1) concentration of Canchim calves.

\begin{tabular}{lcccc}
\hline Haplotype & BW & WW $\left(^{*}\right)$ & YW & IGF-1 \\
\hline V plus DdeI+ with L plus DdeI+ & $0.52 \pm 0.76$ & $2.32 \pm 5.91$ & $4.26 \pm 7.42$ & $13.51 \pm 15.59$ \\
V plus DdeI+ with L plus DdeI- & $-0.67 \pm 0.79$ & $-1.24 \pm 5.60$ & $2.57 \pm 7.47$ & $16.29 \pm 15.91$ \\
L plus DdeI- with L plus DdeI+ & $1.20 \pm 0.44$ & $3.56 \pm 3.35$ & $1.69 \pm 4.37$ & $-2.78 \pm 9.06$ \\
\hline
\end{tabular}

* Significant effect (F test, $\mathrm{p}<0.05$ ) of substitution of L plus DdeI- haplotype with L plus DdeI+ haplotype.

Kemenes et al. (1999) reported an AluI V allele frequency of 0.28 for Charolais taurine cattle, which contributed $5 / 8$ of the Canchim genome. However, for Zebu indicine cattle, which account for the remaining proportion of the Canchim genome, almost all studies have shown fixation of the AluI L allele (Kemenes et al., 1999; Tambasco et al., 2000; Curi et al., 2006), except for the study by Unanian et al. (2000) of Nelore indicine cattle, which the reported frequencies of 0.85 for the $\mathrm{L} / \mathrm{L}$ genotype and 0.15 for the L/V genotypes. Thus, as expected, the allelic frequencies observed by us for Canchim calves were intermediate between those of the two foundation breeds. The genotype and allele frequencies obtained by us for the DdeI polymorphism differ from the standard reported for European breeds (B. taurus). For taurine breeds, Yao et al. (1996) reported Holstein cattle $D d e I$ genotype frequencies of 0.74 (Dde $\mathrm{I}+/ D d e \mathrm{I}+), 0.24$ (Dde $\mathrm{I}+/ D d e \mathrm{I}-)$ and 0.02
(DdeI-/DdeI-), whereas Ferraz ALJ (2001, MSc Dissertation, São Paulo State University, Jaboticabal, SP, Brazil) reported Simmental DdeI genotype frequencies of 0.81 $(D d e \mathrm{I}+/ D d e \mathrm{I}+), \quad 0.14 \quad(D d e \mathrm{I}+/ D d e \mathrm{I}-)$ and 0.05 (DdeI-/DdeI-). No studies on the haplotypes were found in the literature. Thus, few inferences can be made regarding the haplotypes in relation to the two genetic groups that were used to produce the Canchim breed. However, our results indicate that the $\mathrm{V}$ plus $D d e \mathrm{I}+$ haplotype can only be derived from the Charolais breed.

The higher weaning and yearling weights obtained for the AluI polymorphism L/L genotype differed from those reported by Schlee et al. (1994a), who reported an association between higher weights and the heterozygous genotype. However, Di Stasio et al. (2002) found no evidence of an association between this polymorphism and growth or carcass traits in the same breed. Tambasco et al. (2003), 
studying Canchim x Nelore, Simental x Nelore and Angus $x$ Nelore crossbred beef cattle, observed a higher weight gain between birth and weaning in animals with the $\mathrm{L} / \mathrm{L}$ genotype compared to those with the $\mathrm{L} / \mathrm{V}$ genotype, while the opposite was noted between weaning and one year of age. In a review, Switonski (2002) concluded that most studies found lower growth rates in $\mathrm{V} / \mathrm{V}$ cattle compared to those with the other two genotypes (Chrenek et al., 1998; Oprzadek et al., 1999; Sirotkin et al., 2000; Grochowska et al., 2001). These conflicting results suggest that the AluI polymorphism is not directly responsible for the phenotype variations and that the contradictory data can be explained by differences in the linkage disequilibrium between markers and quantitative trait loci (QTL) between the various populations studied, or by different epistatic interactions between the genetic bases of these populations and QTL. On the other hand, it is interesting to note that in beef cattle, in addition to the direct effect of $\mathrm{GH}$ on growth, its effect on milk yield can also affect the phenotype of the animals. If the effects of the alleles on milk yield and growth were antagonistic, this factor would explain part of these controversial results, especially those regarding weaning and postweaning weight. Since the V allele of the AluI polymorphism is rare, or does not exist, in Zebu cattle, the chromosome region corresponding to this restriction site in Canchim cattle carrying this allele probably originated from the Charolais breed. Canchim cattle heterozygous at the Alu $\mathrm{I}$ locus are therefore also expected to be heavier because Charolais taurine cattle are normally heavier than Nelore indicine cattle, especially when the production system favors the expression of these differences.

Although the DdeI polymorphism does not cause an amino acid substitution in the protein sequence, Yao et al. (1996) observed a highly positive association between the DdeI+ allele and milk, fat and protein yield in Holstein cattle. With respect to growth traits, no data are available in the literature to permit comparison with our present results, probably because the polymorphism is silent, thus not arousing the interest of researchers.

The results of the effect of the haplotypes on the traits analyzed, in contrast to those observed for the separate genotype distributions, seem to better explain the variation observed by us in the estimated breeding values.

It is interesting to note that the differences in weaning weight were not accompanied by differences in yearling weight as would be expected. The effect of substitution with the L plus $D d e \mathrm{I}+$ haplotype was positive for the three production traits analyzed, although the standard error found in our analysis did not indicate that the values obtained were significantly different from zero, except for the effect of substitution of L plus DdeI- with L plus DdeI+ on birth weight. The effect of substituting haplotype $\mathrm{V}$ plus $D d e \mathrm{I}+$ with haplotype L plus DdeI- was negative for weaning weight and positive for yearling weight. These results might be explained by antagonistic effects of some haplotype on growth and maternal ability.

The lack of effect of the $G H 1$ genotypes on plasma IGF-1 concentration at weaning was due to the wide variation observed in this trait, as demonstrated by its coefficient of variation $(58.72 \%)$, indicating that a very large number of animals would be necessary to observe significant effects. In addition, collection of a single blood sample for the determination of IGF-1 does not seem to be an appropriate strategy since it does not permit assessment of the release profile of this growth factor. Schlee et al. (1994b) reported higher plasma GH levels in L/L cattle, a finding also reported by Sorensen et al. (2002), whereas heterozygous $\mathrm{L} / \mathrm{V}$ cattle presented more elevated plasma IGF-1 levels. In contrast, Grochowska et al. (2001) found a positive association between the $\mathrm{V} / \mathrm{V}$ genotype and peak $\mathrm{GH}$, whereas higher IGF-1 levels were associated with the L/L genotype. These controversial results might be attributed to the lack of uniformity of the population studied in terms of breed, sex, age and productive capacity, as well as to the experimental method used.

In conclusion, based on the analysis of the genotype frequencies and of the effects of the polymorphisms on the different weight parameters it is evident that the restriction enzymes analyzed determine haplotypes that should be considered in the study of growth hormone 1 gene polymorphisms. In addition, the results indicate that the $G H 1$ polymorphisms can be used for the selection for growth traits, with the haplotype containing the two restriction sites provoking a greater increase in weaning weight in the Canchim herd studied.

\section{References}

Boldman KG, Kriese LA, Van Vleck LD, Van Tassel CP and Kachman SD (1995) A Manual for Use of MTDFREML: A Set of Programs to Obtain Estimates of Variance and CoVariance. Agricultural Research Service, Lincoln, 125 pp.

Chrenek P, Kmet J, Sakowski T, Vasicek T, Huba J and Chrenek J (1998) Relation-ships of growth hormone genotypes with meat production traits of Slovak Pied bulls. Czech J Anim Sci 43:541-544.

Curi RA, Palmieri DA, Suguisawa L, de Oliveira HN, Silveira AC and Lopes CR (2006) Growth and carcass traits associated with GH1/Alu I and POU1F1/Hinf I gene polymorphisms in Zebu and crossbred beef cattle. Genet Mol Biol 29:56-61.

Davis ME, Boyles SL, Moeller SJ and Simmen RC (2003) Genetic parameter estimates for serum insulin-like growth factor-I concentration and ultrasound measurements of backfat thickness and longissimus muscle area in Angus beef cattle. J Anim Sci 81:2164-2170.

Di Stasio L, Sartore S and Alberta A (2002) Lack of association of GH1 and POU1F1 gene variants with meat production traits in Piedmontese cattle. Anim Genet 33:61-64.

Goodman HM (1993) Growth hormone and metabolism. In: Schreibman MP, Scanes CG and Pang PKT (eds) The Endocrinology of Growth, Development and Metabolism in Vertebrates. Academic Press, San Diego, pp 93-115. 
Gordon DF, Quick DP, Erwin CR, Donelson JE and Maurer RA (1983) Nucleotide sequence of the bovine growth hormone chromosomal gene. Mol Cell Endocrinol 33:81-95.

Grochowska R, Sorensen P, Zwierzchowski L, Snochowski M and Lovendahl P (2001) Genetic variation in stimulated GH release and in IGF-I of young dairy cattle and their associations with the leucine/valine polymorphism in the GH gene. J Anim Sci 79:470-476.

Kemenes PA, Regitano LCA, Rosa AJM, Packer IU, Razook AG, Figueiredo LA, Silva NA, Tchegaray MA and Coutinho LL (1999) k-casein, b-lactoglobulin and growth hormone allele frequencies and genetic distances in Nelore, Gyr, Guzerá, Caracu, Charolais, Canchim and Santa Gertrudis Cattle. Genet Mol Biol 22:539-541.

Nicoll CS, Mayer GL and Russell SM (1986) Structural features of prolactins and growth hormones that can be related to their biological properties. Endocr Rev 7:169-203.

Oprzadek J, Dymnicki E, Zwierzchowski L and Lukaszewicz M (1999) The effect of growth hormone $(\mathrm{GH}), \kappa$-casein (CASK) and $\beta$-lactoglobulin (BLG) genotypes on carcass trait in Friesian bulls. Anim Sci Pap Rep 17:85-92.

SAS (1999) Statistical Analysis System, Systems for Windows. SAS Institute Inc., Cary, NC.

Schlee P, Graml R, Rottmann O and Pirchner F (1994a) Influence of growth hormone genotypes on breeding values of Simmental bulls. J Anim Breed Genet 111:253-256.

Schlee P, Graml R, Schallenberger E, Schams D, Rottmann R, Olbrich-Bludau A and Pirchner F (1994b) Growth hormone and insulin-like growth factor 1 concentrations in bulls of various growth hormone genotypes. Theor Appl Genet 88:497-500.
Sirotkin AV, Chrenek P, Makarevich AV, Huba J and Bulla J (2000) Interrelation-ships between breed, growth hormone genotype, plasma IGF-I level and meat performance in bulls of different ages. Arch Anim Breed 43:591-596.

Sorensen P, Grochowska R, Holm L, Henryon M and Lovendahl P (2002) Polymorphism in the bovine growth hormone gene affects endocrine release in dairy calves. J Dairy Sci 85:1887-1893.

Switonski M (2002) Molecular genetics in beef cattle breeding - A review. Anim Sci Pap Rep 20:7-18.

Tambasco DD, Alencar MM, Coutinho LL, Tambasco AJ, Tambasco MD and Regitano LCA (2000) Caracterização molecular de animais da raça Nelore utilizando microssatélites e genes candidatos. Rev Bras Zootec 29:1044-1049.

Tambasco DD, Paz CCP, Tambasco-Studart MD, Pereira AP, Alencar MM, Freitas AR, Coutinho LL, Packer IU and Regitano LCA (2003) Candidate genes for growth traits in beef cattle crosses Bos taurus x Bos indicus. J Anim Breed Genet 120:51-56.

Unanian MM, Barreto CC, Freitas AR, Cordeiro CMT and Josahkian LA (2000) Associação do polimorfismo do gene do hormônio de crescimento com a característica peso em bovinos da raça Nelore. Rev Bras Zootec 29:1380-1386.

Yao J, Aggrey SE, Zadworny D, Hayes JF and Kuhnlein U (1996) Sequence variations in the bovine growth hormone gene characterized by single-strand conformation polymorphins (SSCP) analysis and their association with milk production traits in Holsteins. Genetics 144:1809-1816. Associate Editor: Luiz Lehmann Coutinho

License information: This is an open-access article distributed under the terms of the Creative Commons Attribution License, which permits unrestricted use, distribution, and reproduction in any medium, provided the original work is properly cited. 